\title{
A vezetői megbízással rendelkező szociális szolgáltatást nyújtó személyek vezetőképzésének koncepciója a Semmelweis Egyetemen
}

\author{
Antal Zsuzsanna, Bálity Csaba, Cserháti Zoltán, Galambos László, Ivády \\ Vilmos, Joób Máté, Nistor Katalin, Nyitrai Imre, Révész Éva \\ a szerzők valamennyien a Semmelweis Egyetem Egészségügyi Közszolgálati Karának \\ munkatársai
}

A szociális ágazat átalakított továbbképzési rendszerében 2018-ban kötelező elemként megjelent a vezetőképzés. Az Emberi Erőforrások Minisztériuma elsőként a Semmelweis Egyetemet jelölte ki a képzés megszervezésére. A képzési program négy jól körülhatárolható tanegységből áll, ezeket moduloknak nevezzük. Jelen tanulmányban arra teszünk kísérletet, hogy a szélesebb szakmai közvéleménnyel is megismertessük azokat az elképzeléseket, víziókat, amelyek mentén a program tartalma kialakult. Az említett négy modul koncepciójának, tartalmi elemeinek és a kezdeti időszak tapasztalatainak ismertetésére a képzés vezető oktatóit kértük fel, akik az alábbiakat különálló alfejezetekben mutatják be, nem csupán azok számára, akik a jövőben a Semmelweis Egyetem hallgatói lesznek, hanem valamennyi érdeklődő szociális ágazatban dolgozó szakembernek.

Kulcsszavak: vezetőképzés, szociális ágazat, oktatási program, Semmelweis Egyetem, modul

In 2018 as a compulsory element an executive training program was introduced to the social education and training system. Semmelweis University was appointed by the Ministry of Human Capacities to realize and carry out the executive training program consisting of four units, called and later referred as modules. This paper aims to introduce the ideas and visions along which the content of the program has been developed to the wider professional audience. To cover all the information and crucial aspects the main stakeholders of the training were asked to present the concepts, content elements and experiences of the four modules, in separate sub-chapters.

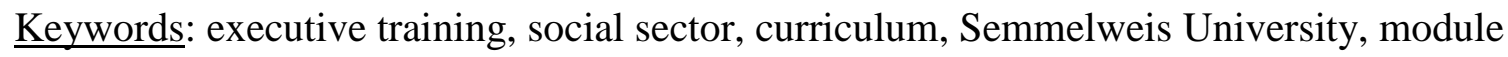




\section{Bevezetés}

Magyarországon a szociális, gyermekjóléti és gyermekvédelmi tevékenységet végző intézmények vezetői munkakörének ellátásához 2018 előtt nem volt biztosítva egy egységes és minden vezető számára kötelezően elvégzendő képzés, amely a vezető szerephez szükséges átfogó ismereteket és készségeket biztosította volna, illetve segítette volna a tudatos és alapos felkészülést a vezetői posztra.

A szociális ágazaton belül müködő továbbképzési rendszer egyes elemei érintették ugyan a vezetés és menedzsment területét is, azonban a tavalyi évvel megszünt az ebböl a szempontból leginkább relevánsnak tekinthető szociális szakvizsga, s helyette kétszintü szociális vezetőképzést vezettek be. A szociális igazgatásról és szociális ellátásokról szóló 1993. évi III. törvény 2018. január 1-jétől tartalmazza a vezetőképzés törvényi alapját, miszerint:

„92/D. § (2) A személyes gondoskodást nyújtó szociális, gyermekjóléti és gyermekvédelmi tevékenységet végző, vezetői megbízással rendelkező személyek külön jogszabályban meghatározottak szerint vezetőképzésen vesznek részt.

(3) A vezetőképzést végző szervezetet a szociál- és nyugdíjpolitikáért felelős miniszter jelöli ki."

Ezáltal azon személyek, akik személyes gondoskodást nyújtó szociális, gyermekjóléti és gyermekvédelmi tevékenységet végeznek, s emellett vezetői megbízással rendelkeznek, a törvényben foglaltaknak megfelelően új vezetőképzésen kötelesek részt venni. Az új rendszer célja, hogy felkészítse az ágazat intézményvezetőit a rendszerszemléletre, amely újszerü megközelítést jelent a vezetők saját szerepének és az általuk irányított intézmény müködésének tekintetében egyaránt. Emellett korszerü, a hatályos jogszabályoknak megfelelő ismeretekre tudnak az átalakított képzési rendszer keretében szert tenni, amely segíti őket a szakmai feladatok ellátásában és az intézmény vezetésében. Az átfogó tudást közvetítő, egységes rendszer célja többek között az is, hogy az olykor merőben eltérő háttérrel rendelkező személyek vezetéshez szükséges kompetenciákat szerezzenek, vagy a meglévő kompetenciáikat, tudásukat fejlesszék, s ezáltal eredményesebbé váljon a szociális ágazatban dolgozó vezetők munkája. A minőségi vezetés kihat az egész szervezet müködésére, ami láncreakcióban végül is az ellátottaknak nyújtott segítség minőségében, illetve annak hatékonyságában nyilvánul meg. Az intézményvezetők a képzés során megszerzett szakmai és gyakorlati vezetői tudásukkal a fenntartóikat is támogatni tudják stratégiai döntések meghozatalában. Ezek alapján biztonsággal állíthatjuk, hogy az ágazat egészének szüksége van a képzés nyújtotta hatékony vezetői kompetenciák közszolgáltatást végző intézményekben való megjelenésére.

Cél, hogy egy olyan ágazati vezetőképzés müködjön, amely alaposan és sokrétűen felkészíti a leendő vezetőket a vezetői szerepükre, a már gyakorló vezetőket pedig folyamatosan fejleszti. A megfelelö képzés a vezetői szerepkörbe tartozó feladatok minden fontos aspektusára kitér, biztosítja a szervezési és vezetési ismereteket, bemutatva azok alkalmazási gyakorlatát, hatékony kommunikációs eszköztár biztosításával csapatépítő, konfliktuskezelö és önismereti technikák elsajátítását nyújtja, valamint biztosítja a hatályos jogszabályok megismerését, értelmezését, és segít azok alkalmazásában. A képzés tehát igyekszik konkrét eszközöket nyújtani a szociális vezetők számára a készségfejlesztés, valamint a jó gyakorlatok megismerése által, és ezt hivatott támogatni a képzés részeként végzendő projektmunka is. Így a képzésen való lelkiismeretes, elhivatott részvétel hozzájárul a szociális vezetők munkájának minőségi és professzionális javulásához.

A szociális szféra képzési és továbbképzési rendszerének átalakítása az ágazatban dolgozó valamennyi szakembert érinti. Az EFOP 3.8.2 és a VEKOP 7.5.1 tükörprojektek részeként megvalósuló vezetőképzés elvégzése a korábbi szakvizsgarendszer kiváltásaként nemcsak új feladatot ró a vezetőként dolgozó szakemberekre, de lehetőséget is teremt arra, hogy olyan 
korszerü és hasznos tudást, tapasztalatokat és nem utolsósorban személyes kapcsolatokat szerezzenek, amelyek segítségével hatékonyabban végezhetik munkájukat. Az innovatív képzés kereteit a 25/2017 (X. 18.) EMMI rendelet határozza meg. A jogszabály a vezetőképzésre kötelezettek körén túl, annak szintjeit, időkeretét és az elméleti és gyakorlati képzés arányát is elöírja. Ezenkívül kijelöli azokat a felsőoktatási intézményeket is, amelyeket alkalmasnak talál a képzés megszervezésére és a curriculum kidolgozására. Az állami felsőoktatási intézmények közül - két egyházi egyetem mellett - a Semmelweis Egyetem került nevesítésre a jogszabályban. A három intézmény közül úttöröként a Semmelweis Egyetem Egészségügyi Közszolgálati Karán dolgozták ki a hatósági jellegü - azaz az érintett vezetők számára kötelező, az adott vezetői munkakör betöltésének jogszabályi feltételét képező -, kétszintü vezetőképzés képzési és oktatási programját, amelyet a rendeletnek megfelelően az illetékes miniszter hagyott jóvá, 2018 tavaszán. A képzési program négy jól körülhatárolható tanegységből áll, ezeket moduloknak nevezzük. Jelen tanulmányban arra teszünk kísérletet, hogy a szélesebb szakmai közvéleménnyel is megismertessük azokat az elképzeléseket, víziókat, amelyek mentén a program tartalma kialakult. Az említett négy modul koncepciójának, tartalmi elemeinek és a kezdeti időszak tapasztalatainak ismertetésére a képzés vezető oktatóit ${ }^{1}$ kértük fel, akik az alábbiakat különálló alfejezetekben mutatják be, nem csupán azok számára, akik a jövőben a Semmelweis Egyetem hallgatói lesznek, hanem valamennyi érdeklődő szociális ágazatban dolgozó szakembernek.

\section{Ágazatspecifikus ismeretek a szociális vezetőképzésben}

A szociális vezetőképzés mesterszintü, alapozó képzésének tervezésekor - az előzetes kutatások és hatástanulmányok, valamint a személyes konzultációk során begyüjtött, több száz, dokumentált vélemény és hozzászólás alapján - láthatóvá vált, hogy a szociális

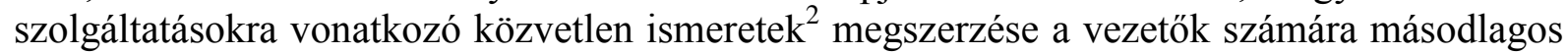
fontosságú. Ezeknek az adatfelvételeknek a fó tanulságai a vezetőképzés oktatási programjába kerültek beépítésre, önálló publikációként nem jelentek meg. Bár az említett eredmények szintén számot tarthatnak a szakmai közvélemény érdeklődésére, jelen tanulmány keretein túlmutatnak, ezért terveink szerint, külön közleményként fogjuk publikálni az adatokat.

A szakmai ismeretek a széttagolt szolgáltatási rendszernek, a távoli és sokszor szakmailag nehezen egyenértéküsíthető területek (a gyermekvédelemtől a fogyatékossággal élő személyek fejlesztő foglalkozásáig, a tartós bentlakásos ellátásoktól a szenvedélybetegek nappali intézményéig, a bölcsődéktől a javítóintézetekig) müködésének ellenére minden vezető számára elérhetők és elérendők. Ennek háttere egyrészt a szociális, felsőfokú oktatási rendszer - többé-kevésbé gyakorlatias - szakmai ismeretanyaga, másrészt a korábbi, ún. szakvizsgarendszer által nyújtott tudás, szakmai tartalom.

Ez a szaktudás azonban nem szolgálta, nem szolgálhatta az általános, teljes ágazatra megfeleltethető vezetői készségek kialakulását és megerősítését. A szakmai szemléletmód, szolgáltatási ethosz - kis túlzással - annyiféleképpen alakult, ahány képzés megszervezésre

\footnotetext{
${ }^{1}$ Ágazatspecifikus ismeretek - Nyitrai Imre; Gazdálkodás - Ivády Vilmos; Vezetés és szervezés - Antal Zsuzsanna, Cserháti Zoltán, Galambos László, Nistor Katalin, Révész Éva; Menedzsmentkészségek és kompetenciák - Joób Máté.

${ }^{2}$ Közvetlen ismeret alatt értve az egyes szolgáltatások és szolgáltatási elemek konkrét müködésének és müködtetésének ismereteit, a szolgáltatások napi gyakorlatának részletszabályait, jellemzöit és müködési ismérveit.
} 
került. A tananyag összeállításakor tehát az egyik alapvetés a szolgáltatásközpontú látásmód, szemlélet hiánya volt.

A kutatásokban részt vevő vezetők - mindemellett - egyértelmủen a vezetői szerepükben, a vezetői feladataik ellátáshoz kértek és kérnek muníciót. Konkrét, használható eszközökre tartanak igényt, amellyel a mindennapi munkájukat hatékonyabban és hatásosabban képesek végezni.

A fenti szükségletekből, feltárt elvárásokból kiindulva a szociális ágazat specifikus ismeretek képzési blokkba tartozó tantárgyak középpontjában a teljes szociális, gyermekjóléti és gyermekvédelmi rendszer, összefoglaló nevén a szociális ellátórendszernek mint a társadalompolitika egyik fontos alrendszerének a tágabb, értékelvü megközelítése áll. A szociális szolgáltatási rendszer gyenge elemeinek, müködési anomáliáinak a képzésben részt vevőkkel közösen feltárt jellemzői adják tehát a modul konkrét közegét, alapját.

A tananyag egyes számmal ellátott moduljának tematikus fókuszait három tantárgy köré csoportosítva építettük fel.

\section{Rendszerek és környezetük}

A tantárgy központi tézise, hogy - a már említett, létező széttagoltság, szegmentáltság ellenére - a szociális szakma egységes. Ezt az egységet a közös szemléletmód kialakításával, megerősítésével, hangsúlyozásával szolgálhatjuk a legjobban, ez pedig a mindenek felett álló ügyfélközpontúság.

A szakma (a szociális ágazat) szegmentált müködésmódja helyett a keretek rugalmas, de fenntartható alakításával, a szociális segítés közös értelmezésével, saját, vezetői szerepekbe illesztésével célszerü a szolgáltatási rendszert üzemeltetni. Ez a kijelentő mondat semmiképpen sem csupán egy kívánalom megfogalmazása, hanem részben a modul, de nagyrészt a tantárgy keretei között átélt gyakorlat kialakításával elmélyítő és készségeket támogató eszközként müködik.

Az ellátórendszer müködésének áttekintéséhez szükséges a szociális ágazatot a közpolitikák tágabb rendszerében is elhelyezni, a kapcsolódásokat felismerni. A szociális védelem rendszerének számbavételével, a szociálpolitika céljainak, eszközeinek és feladatainak gyakorlati szempontú áttekintésével minden vezető el tudja helyezni saját szolgáltatásait is a teljes rendszerben.

A szociális vezetőknek kevés alkalma jut a teljes ágazat müködési logikáját áttekinteni, megismerni és értelmezni a szociális diagnózis lényegét, a szükségletekre alapozott szolgáltatástervezés előnyeit és hátrányait, lehetőségeit és veszélyeit.

Ahhoz, hogy a hazai szociális ellátórendszer müködési kereteit pontosan megismerjük, szükséges kitekinteni más alrendszerekre is, továbbá pontosan meg kell ismerni azokat a peremfeltételeket, amelyek a hazai ellátórendszer sajátosságait alapvetően meghatározzák. Szükséges megismerni a szociális és gyermekvédelmi ellátással leginkább kölcsönhatásban álló szakpolitikák - elsősorban az egészségpolitika, az oktatáspolitika, a foglalkoztatáspolitika - sajátosságait, s feltárni az együttmüködés lehetőségeit, keretrendszerét. A tantárgy ehhez személyes példákra alapozott, közös, jó gyakorlat bemutatással kíván segítséget nyújtani.

A tantárgy két legfontosabb eleme a szociális szolgáltatásokra vonatkozó legfontosabb kérdések őszinte megfogalmazása, valamint egy konkrét esetre hatékonyan reagálni képes szolgáltatási paletta esettanulmányra épített, közös kialakítása. 
A közösen megfogalmazott kérdések érintik az egyén és a család, a közösségek és az állam felelősségét és kötelezettségét, az alapszolgáltatások és szakosított ellátások közötti különbségeket, a szakmai identitás kialakulásának kérdéseit és az ágazat társadalmi beágyazottságát és megbecsültségét is.

A részt vevő hallgatók saját tudásuk tesztelése mellett képet kapnak a szerteágazó ellátások szinergiáiról, és tudatosítják a szabályozással le nem fedett vagy le nem fedhető szükségletekre adható válaszok lehetőségeit.

Közösen kialakított válaszokat keres a tantárgy az ágazati jövőképröl, a szakma és/vagy hivatás kérdéskörére, a célcsoport-specifikus és/vagy univerzalisztikus müködés dilemmáira.

A tantárgyon belül egy egyénileg megfogalmazott, de csoportosan feldolgozott feladat keretei között kiemeljük a hallgatói csoport által képviselt szakmai értékeket és alapelveket is.

Külön elemet jelent a fenntartók és intézmények kapcsolatrendszerének elemzése, a jó és rossz müködési módok, lehetőségek számbavétele is.

\section{Jog és alkalmazása}

A jog területén talán kiemelten fontos - egyben különösen nagy kihívás - annak érvényesítése, hogy a szociális vezetőképzés elsődleges célja nem lexikális tudás átadása, hanem kompetenciafejlesztés. Nem szerettünk volna tehát abban gondolkodni, hogy a jog és alkalmazása tantárgy keretében a szociális ágazatot érintő hatályos jogszabályok tartalmát, azok történeti fejlődését, eddigi változásait ismertetjük. Meglátásunk - és immár tapasztalatunk - szerint az ezzel kapcsolatos gyakorlati ismeretek jelentős részével az érintett vezetők rendelkeznek, a klasszikus jogelméleti ismeretek pedig a szociális vezetői kompetenciák fejlesztését kevéssé szolgálják.

A tantárgy tartalmának tervezésekor abból az előfeltevésből indultunk ki - amit a tantárgy nyitó kérdéseire adott hallgatói válaszok rendkívül magas arányban alátámasztottak -, hogy a vezetők számára többnyire nehezen értelmezhető, állandóan változó, átláthatatlan útvesztőt jelent a jogszabályok világa, amely sokkal inkább nehezíti, akadályozza a munkájukat, mintsem lehetőséget vagy segítséget nyújt számukra a napi vezetői munkában. A képzésben részt vevők ezért mindenekelőtt a társadalmi és szakmai normák természetével, jellegével és szerepével kapcsolatban folytatnak diskurzust, melynek során aztán folyamatosan kirajzolódnak a jogszabályokkal való kapcsolódási pontok, hasonlóságok és különbözöségek is.

A tantárgy egyik fó célja annak megvilágítása, hogy a jogszabályok nemcsak korlátot jelentenek, hanem igazodási pontot, eszközt, sőt szakmai iránytüt biztosítanak a különböző vezetői feladatok ellátásához. Ez azonban annak felismerését is igényli, hogy a joggal kapcsolatos, fent említett negatív attitüd gyakran azért alakul ki, mert a vezető elvész azokban a jogszabályokban, amelyek napi szintü, gyakorlati alkalmazása alapvetően nem felső vezetői feladat, ugyanakkor elvonja az energiát azoknak a joganyagoknak a megismerése és belsővé tétele elöl, amelyek a legmélyebb szakmai tartalommal bírnak.

Ebbe a körbe tartoznak mindenekelőtt az ágazatot érintő nemzetközi egyezmények, illetve a hazai szakpolitikai stratégiák, melyekre ráadásul sokkal kevésbé igazak a jogszabályokat általában érintő kritikák, hiszen jellemzően ritkán módosuló, jól értelmezhető, szociális szakmába vágó szövegekről van szó. Mindemellett ezek azok a jogi dokumentumok, amelyek a legjelentősebb szakmai, szemléletbeli hatásokkal járnak, és alapkövei lehetnek a szakterület szakmai egységességének is, hozzájárulva ahhoz, hogy célcsoportjainkat és az őket érintően 
kialakult élethelyzeteket közös elvek és értékek mentén közelítsük meg, ami különösen fontos ágazati érdek.

A szakpolitikai stratégiákhoz kapcsolódóan lényeges vonulat annak felvetése, hogy ideális esetben a szociális vezető nem pusztán a jogi szabályozás és az egyéb ágazati döntések passzív alanya, hanem olyan szereplö, aki maga is hatással lehet a rendszer müködésére, a szakma fejlődésére, ha ismeri és érti a kormányzati, szakpolitikai müködés logikáját és szempontjait is. Mindez egyúttal az ágazaton belüli szakmai kapcsolatokra, a hálózatosodás és az érdekérvényesítés kérdéskörére is ráirányítja a figyelmet, ami a hallgatói reakciók alapján aktuális és fajsúlyos szempontnak, ugyanakkor fejlesztendö területnek látszik.

Az ügyfélközpontúság gondolatát magára az oktatásra is átültetve különös hangsúlyt fektetünk arra, hogy a jogi tantárgy is oldott, kézzelfogható és élvezhető keretek között folyjon. Mindvégig - bárki számára - könnyedén értelmezhető nyelvezetet használva, életszerü példák, játékok és kooperációt igénylő csoportfeladatok útján irányítjuk a hallgatók figyelmét olyan összefüggésekre, amelyekböl hosszabb távon is hasznosítható felismerések születhetnek. Ahogy a képzés egészében, itt is jelentős terepet biztosítunk az egymástól való tanulásnak, ami sok esetben bármely oktatási módszertannál hatékonyabb eszköznek bizonyul.

\section{Etika és érdekvédelem}

A szociális szektorban dolgozó menedzserrel szemben környezete etikus vezetői magatartást vár el. A vezető mintát ad, magatartása kihat a szervezetre, normát alkot. Szinte minden menedzsmentszintü döntés mögött, illetve azzal együtt megjelennek etikai vonások is, azaz a menedzsmentdöntéseknek etikai dimenziója is van.

A személyes vonatkozások mellett azonban létezik egyfajta szociális ágazati ethosz is, amely a szociális segítés különös jellemzőit foglalja magában, azonban a szakma korántsem egységes ennek feldolgozásában és értelmezésében.

Az etikai vezetés központjában nem szabályok alkotása, hanem az egyértelmű és érthető elvárások megalkotása áll. A kliensek kiszolgáltatottsága a szolgáltatószervezet felé súlyos felelősséget támaszt, amely túlmutat a vezetők egyéni magatartásán. Az etikának meg kell jelenni a szervezeti struktúrában is. Az etikus vezetés elveinek vezetői döntéseken, magatartáson és gyakorlaton keresztül történő érvényesítése a teljes ellátószervezet erkölcsi minőségét meghatározza. A szociális szolgáltatások minőségi megítélésének - éppen a szociális segítés „személytől személyig ható” jellegéből adódóan - fontos alapja a segítők etikus müködése. Ennek biztosítása szociális vezetői feladat.

Az etikai vezetés a szociális szolgáltatást nyújtó szervezetben kiterjed a kiszolgáltatott, korlátozott önrendelkezéssel bíró személyek érdekeinek védelmére is. A tantárgy feltárja, hogy melyek azok a belső szabályrendszer kialakításának és megvalósításának sajátosságai, amelyek az etikai vezetés elvein nyugvó érdekvédelmi normarendszerben testesülnek meg.

A hallgatókkal közösen keresi a tantárgy a választ arra, hogy mik is a releváns ellátott jogok, és ezek milyen sajátosságokkal bírnak a hazai intézményrendszerben, szolgáltatási struktúrában. A szociális vezetőknek fel kell ismernie, hogyan segíthetik elő a rábízott ellátottak érdekérvényesítő képességeinek (önállóságának) megerősítését. A képzés során választ keresünk arra is, hogy hol vannak a határai az ellátottak érdekében, értük és a helyettük hozott döntések helyességének és károsságának, s ebből adódóan mikor kell támogatni az önrendelkezésében korlátozott személy döntéshozatalát, és mikor kell átvállalni döntéseiket. 
Az érdekvédelmi területen tehát az ellátottak, kliensek érdekeinek védelmét és az ellátók, munkavállalók, kollégák (szakszervezeti, közalkalmazotti/munkavállaló tanácsi stb.) érdekvédelmét szükséges megismerni és annak adottságait, erősségeit és gyengeségeit, lehetőségeit és veszélyeit áttekinteni.

A modul összetett célokat fogalmaz meg, azonban a végső cél a szakmai értékek, célok közös megfogalmazása, a szociális vezetés tudatosságának, a tudatos vezetői müködésnek az erősítése.

A modul oktatóinál tutorált hallgatók a saját gyakorlatuk jobbítását célozzák meg. Az ún. belépő esszék - sokféle stílusban, de szinte minden esetben - már kialakult problémákra fókuszálnak, s a lehetséges megoldásokat elemzik, vagy az elmaradt megoldások lehetőségeit keresik.

A szociális vezetők a legtöbb esetben a környezeti változásokra való reagálásban, a sokszor kiszolgáltatottsági érzésben látják a napi müködés legnagyobb gátját. Ezt - a konkrétumokon túl - a kiszámítható, stabil és értékalapú szakmai felfogással, tudatos elhivatottsággal és célorientált müködéssel próbálják az eddig megismert vezetői megoldások kezelni. A konkrét példák hosszan sorolhatók a szakmai innovációk környezeti akadályaitól a fenntartóintézmény kapcsolat nehézségein át a személyes hatékonyság alacsonynak ítélt szintjéig - a közös azonban ezekben is, hogy a szociális vezetők a hatékonyabb segítés megvalósításában, az eszköztelenség mérséklésében érdekeltek. Ebben a „képessé tevésben” próbál a modul oktatói csapat a szociális vezetők segítségére lenni.

A modul mottója is lehetne: „Egyetlen szervezet sem támaszkodhat zsenikre, mert azokból kevés van és megbízhatatlanok. Egy szervezet erejének az a próbája, hogy többet tude felszínre hozni egy közönséges földi halandóból, mint amire az képesnek látszik, előhívja-e rejtett energiáit, hogy azzal másokat is segítsen képességeik kibontakoztatásában. Egy szervezet célja, hogy átlagos embereket átlagon felüli tettekre tegyen képessé."3

\section{Közgazdasági szemlélet fejlesztése a szociális vezetőképzésben}

A ,pénzért értéket” szemlélet megjelenése a közszférában felveti annak szükségességét, hogy a szociális ágazatban dolgozó vezetők is megismerkedjenek ennek a megközelítésnek a tartalmával és az ebből fakadó vezetői lehetőségekkel és persze felelősséggel. Ez a szemlélet kitágíthatja az ágazat munkájának értékelését, ugyanis már nemcsak arról van szó, hogy szabályosan kell ellátni a feladatokat, hanem hogy a szabályosság mellé felzárkózik a hatékonyság, mint eredményességi kritérium, így a természeténél fogva hatékonyság központú közgazdasági gondolkodás szerepe a vezetői döntések meghozatalában felértékelödik.

Ugyanakkor a jelenlegi helyzet úgy jellemezhető, hogy a szociális ágazatban dolgozó intézményvezetők egyrészt jellemzően nem tanultak közgazdaságtant, másrészt munkájuk során egy nagyon kötött pályán mozognak, és azt gondolják, hogy kevéssé van lehetőségük a közgazdasági szemlélet alkalmazására a döntések meghozatala során. A közgazdasági

\footnotetext{
${ }^{3}$ Peter Ferdinand Drucker az Osztrák-Magyar Monarchiában született, a Frankfurti Egyetemen szerzett jogi végzettséget, Londonban dolgozott, mielőtt 1937-ben az USA-ba emigrált, s lett a „menedzsertudományok atyja” (három tucat könyvet írt életében, ebből 15 szól a menedzsmentről, 16 pedig közgazdasági, politikai és társadalmi kérdésekröl) (http://www.ceo.hu; https://www.citatum.hu/idezet/1611).
} 
gondolkodást leegyszerüsítve, egyfajta pénzügyi szemléletnek fogják fel, és ennek megfelelően a napi munkavégzésben megismert gazdasági feladatokkal azonosítják, holott ennél többről, a jó vezetői döntések támogatásáról szól. Úgy gondoltuk, hogy egy olyan megközelítésre van szükség, amelyen keresztül nemcsak megértenek közgazdasági alapfogalmakat és összefüggéseket, hanem felismerik ezek követésének jelentőségét a munkájuk során, ugyanis a szociális szféra számára már elkészült egy pénzügyi-gazdasági ismeretekkel foglakozó szakirodalom (Sümegi 2017).

A fentiek szellemében építettük föl a szociális vezetőképzés közgazdasági modulját, amelyet a pilotképzés oktatási tapasztalatai alapján átalakítottunk. Célkitüzésként az alábbiakat fogalmaztuk meg:

- A szociális intézményvezetők körül és a velük történő dolgok jobb megértése

- Támpontok, készségek a problémák megoldásához

- Néhány konkrét probléma megoldása, esetfeldolgozásokon, példamegoldásokon, kvízeken keresztül

Az alábbiakban kitérünk a képzési modul föbb üzeneteire és az üzenetátadás néhány módszerére.

\section{Mindenki közgazdász?}

Általános vélekedés szerint mintha csak a közgazdászok, a gazdasági szakemberek sajátja lenne a közgazdasági gondolkodásmód, mindenki más pedig más módon gondolkodik. Ennek az elkülönülésnek a feloldását tartottuk az első számú feladatnak, hogy láttassuk velük, hogy a közgazdasági gondolkodásmód nemcsak hogy nem ellentétes az ő gondolkodásmódjukkal, hanem segíti őket abban, hogy jobb, eredményesebb vezetökké váljanak. Már a háztartásban is gazdálkodunk, és közgazdasági döntéseket hozunk, hogy a szükösség keretei között a legjobb választásokat hozzuk meg. Mindenki mérlegel a döntései során: milyen ráfordítással jár a döntés végrehajtása és ez mekkora eredményt hoz. Más szóval döntéseinkhez hozzárendeljük a várható következményeket és értékeljük azok teljesülését.

A közgazdászok lényegében figyelik az emberek viselkedését, és ezek alapján próbálnak felállítani törvényszerüségeket a gazdaság működésére vonatkozóan. A pénzért értéket elv hangsúlyozása, beépítése a vezetői gondolkodásmódba már megjelent az ÁSZ módszertani anyagaiban is, a hatékonyság szempontjából pedig kulcsfontosságú ennek beépítése. Ez a jövő, a jelen túlzottan bürokratikus teljesítmény értelmezése mellett, melyben a jogszabályoknak való megfelelés sokszor elegendő a vezető teljesítményének elfogadásához, ami leértékeli, háttérbe szorítja az innovatív, értékteremtő és hatékonyságra törekvő vezetői munkát. Tekintettel arra, hogy egy képzés, oktatás mindig jövőorientált (is) kell, hogy legyen a közgazdasági modulban nagy hangsúlyt fektettünk a teljeskörüen értelmezett hatékonyság értelmezésére, a vezetői munkában történő megjelenítésére, akkor is, ha ez a jelenlegi tevékenység, illetve feladat finanszírozási rendszerben nem kerül elismerésre. Innentől vezetői belső motiváció, „nyomot hagyni magam után”, szolgálni, nem csak szolgáltatni meggyőződés érvényesülése alapján történhet az értékteremtő munka végzése mindaddig, amíg annak az intézményfinanszírozási, valamint a vezetői értékelési rendszerbe történő beépülése várat magára.

Nagy valószínüséggel állítható, hogy amíg az intézményfinanszírozás nem tükrözi a megvalósult értéket csak a tevékenység elvégzését értékeli, addig jelentős hatékonyságveszteség keletkezik a szociális ellátórendszerben is. Könnyen belátható, hogy ha két egyforma tevékenységet végző intézmény ugyanazon finanszírozásért, bevételért (ami 
társadalmi és egyéni nézőpontból költségért jelenik meg) eltérő minőséget, ellátotti (hozzátartozói, társadalmi) elégedettséget hoz létre, akkor a gyengébben teljesítő intézmény kapacitásai nincsenek kihasználva, rossz munkaszervezés, gyenge vezetői kontroll stb. miatt, ami társadalmi veszteségbe torkollik. És amíg a jobb példák, a jó gyakorlatok követésére nincs motiváció, nincs kényszer, addig esélye sincs a társadalmi veszteség csökkentésének. $\mathrm{Az}$ értékteremtő munkavégzésre történő igény egyre kevéssé táplálkozik belső erkölcsi motivációkból, egyre inkább átveszi ennek szerepét a pénzügyi ösztönzés. Erre egy nagyon egyszerü példa: ha folyik a csap, akkor miért zárjuk el? Azért, mert magasabb lesz a vízszámla, és akkor többet kell fizetnünk, vagy azért (is), mert miért folyatnánk feleslegesen tovább a vizet, ha nem használjuk. Nyilván a pénzügyi ösztönzés hatása egyre fontosabb, az értékelvü megközelítést a nevelés képes rögzíteni a fogyasztókba.

A szociális szféra, de általában a közszolgáltatások körében mintha késne ennek a felismerése és különösen az ehhez történő alkalmazkodás. Mintha két külön csoportja létezne a dolgozóknak a magyar munkaeröpiacon. Az egyik elhivatottságból, míg a másik önérdekből dolgozik, és az elöbbiek dolgoznak a közszférában, nonprofit szervezeteknél. Ebben lehet igazság, de azért általánosságban igaz a közszférában, hogy ha nincs érdekeltség a több, jobb teljesítményre, akkor a munkahelymegtartáshoz szükséges teljesítmények minimalizálása mutatja meg, hogy ez a munkaerő is racionálisan gondolkodik és cselekszik.

\section{A menedzsmenttel szembeni elvárások változása}

A modul első részében kifejtett gondolatok megalapozzák a menedzsmenttel szembeni elvárások változásait. Kiemelt helyre került a teljesítmény értékelése, és a teljesítményt megalapozó döntések és azok következményeinek az értékelése. A teljesítmény értékelésében a hatékonyság javítása a fó vezérlőelv, erre épülnek fel az értékeléshez használható indikátorok. Egyfelől a termelékenység, másfelől a fajlagos költségek mentén mérhetjük a szociális munka teljesítményét. A termelékenység fizikai mértékegységekben mutatja a ráfordítás (élőmunka) egy egysége és az eredmény kapcsolatát. Ilyen mutatószám például az egy gondozóra jutó gondozási órák száma a házi segítségnyújtásban vagy az egy gondozóra jutó gondozottak száma a bentlakásos intézményekben. A fajlagos költségmutatók a tevékenység egy egységére vagy az igénybe vett infrastruktúra egy egységére vetített költségeket fejezik ki. Ilyen például az egy gondozási órára vagy gondozottra, illetve az 1 épület $\mathrm{m}^{2}$-re jutó költség. A menedzsmentmunka értékelésében olyan indikátorokat kell kialakítani, amelyek nemcsak a tevékenység elvégzését, annak költségeit, hanem a keletkező eredményeket, azaz hasznosságokat is figyelembe veszik, hogy értékelhessük a hatékonyságát a feladatok elvégzésének. Például ha két ugyanolyan költségvetésböl gazdálkodó, hasonló feladatot ellátó intézmény esetében eltér az ellátottak elégedettsége, akkor nagy valószínüséggel eltérő hatékonyságról beszélünk, mert ugyanakkora ráfordításból eltérő eredmények születnek.

Az oktatás során nagyon érdekes volt megtapasztalni, hogy az eredményes vezetői munkának az alábbi lehetséges korlátai közül melyekre helyezték a hangsúlyt: pénz, idő, erőforrás, hatalom, gondolkodásunk. A képzésben részt vevő hallgatók a gondolkodási korlátot jelölték meg a leginkább akadályozó tényezőnek, amivel lényegében alátámasztották, illetve igazolták a modul célkitüzéseinek helyességét.

A szervezeti teljesítmény értékelésében három fő szempont került kiemelésre: a pénzügyi, a szabályossági és a hatékonysági. A pénzügyi szempont a szervezeti müködés, a feladatellátás pénzügyi eredményét veszi alapul, melynek mércéje a költségvetési intézményeknél a maradvány, illetve a lejárt szállítói tartozás. Indikátora a gazdálkodái egyenleg, illetve a maradvány/lejárt adósság aránya a költségvetési előirányzathoz képest. A szabályossági 
szempont értelemszerüen a vonatkozó jogszabályok betartására vonatkozik. Indikátora a feltárt szabálytalanságok száma, illetve értéke (ha releváns) a költségvetéshez viszonyítva. Ez az indikátor csak korlátozottan használható, mert az ellenőrzések előfordulásának függvénye, hogy keletkezik-e ilyen adat. A hatékonysági szempont a legteljesebb teljesítményindikátor, mert az erőforrás-felhasználással szemben a keletkező eredményt/hasznosságot a legteljesebben veszi figyelembe, magában foglalva a szakmai eredményeket is.

Az alábbi ábra a vezetővel szembeni elvárások változását mutatja, ami szintén irányt szabott a modul tartalmi elemeinek a meghatározásában.

\section{- Elvárások súlypontjainak megváltozása:}

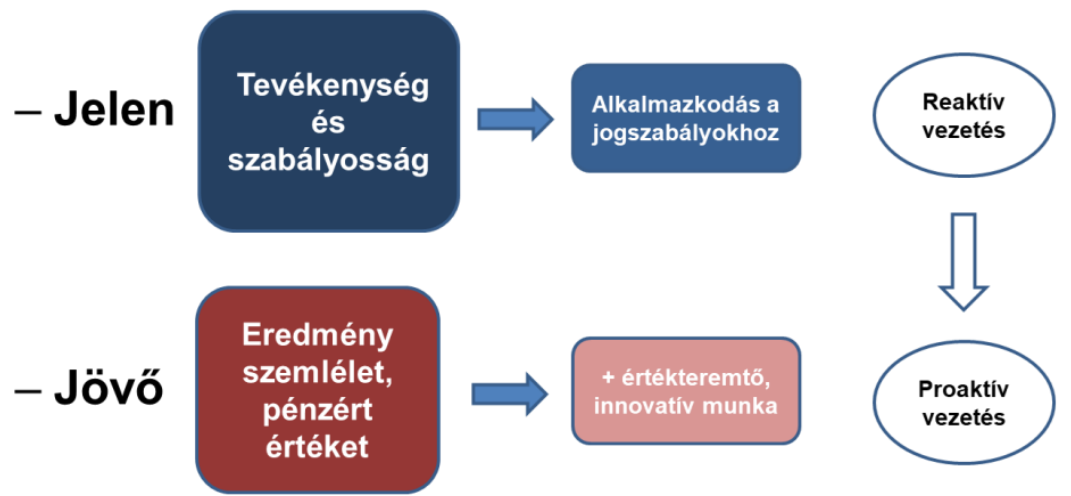

1. ábra. Szociális intézmények gazdálkodási környezete

\section{Vezetöi döntések közgazdasági megalapozása}

A vezetői döntési körre felfüzve (lásd 2. ábra) kerültek bemutatásra és megbeszélésre a jó döntéseket megalapozó közgazdasági ismeretek. Már maga a döntési helyzet is értelmezést, megértést kíván, hogy később a döntés előkészítése és maga a döntés, illetve végrehajtása értékelhető legyen, és a tapasztalatok elvezessék a vezetőket a jobb döntésekig. A szükösségválasztás-választás értékelése folyamatban, bár igen kötött pályán mozognak a szociális intézmények, a választás lehetősége, alternatívák mérlegelése többször adott, mint gondolnánk.

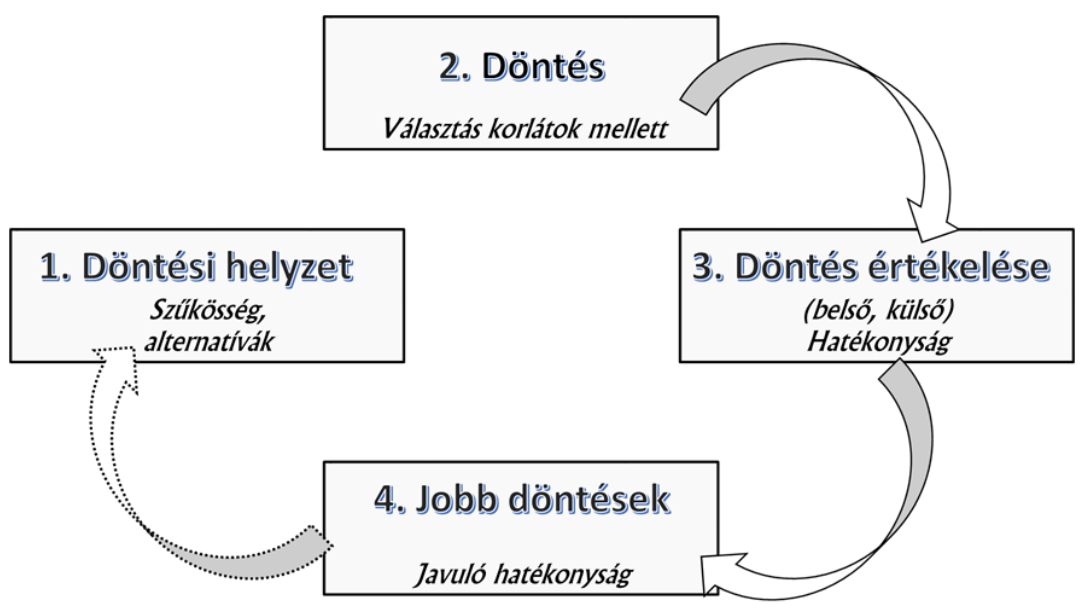

2. ábra. A vezérfonal: gazdasági döntések sorozata 
Döntések és azok következményeinek értelmezésében a ráfordítás-eredmény mentén a teljeskörüségre helyeztük a hangsúlyt. A vezetőknek nemcsak intézményi nézőpontból, hanem a kliensek/hozzátartozók, az intézményt körülvevő közösség, a fenntartó és a finanszírozó nézőpontjából is gondolkodniuk kell, hogy sikeres vezetők lehessenek. Ezért az általuk végzett tevékenység vagy tervezett projekt szempontjából mérlegelni kell a keletkező előnyöket-hátrányokat a különböző nézőpontok szerint.

A vezetők döntései túl kell, hogy mutassanak a feladatellátás, jogszabályi megfelelés kipipálásán. Az állam a minimumfeltételekkel ad egy indirekt szabályozást, ha adott számú gondozottra megvan a gondozói létszám, akkor a minőségi ellátás lehetősége is megvan, de hogy a lehetőségből valóság legyen az a szolgáltatást nyújtó intézményvezető értékalkotó tevékenységén, finanszírozási érdekeltségen túlmutató igényességén, önmegvalósítási igényén múlik.

Ez a megközelítés, az eddigi oktatási tapasztalatok alapján eredményesnek látszik. Hozzá kell tenni, hogy az első pilotcsoport oktatása rávilágított arra, hogy a közgazdaságtant ebben a rövid órakeretben és ennek a célközönségnek nem lehet, nem szabad a megszokott formában, a közgazdasági tankönyvek logikája szerint oktatni. Ezért a tananyag és föleg az oktatás módszertana jelentősen változott a program során, és a változtatások helyességét a hallgatói visszajelzések is alátámasztják.

A döntések megalapozását és értékelését ma már nem lehet kontrolling eszközök használata nélkül jól megvalósítani, ezért a közgazdasági gondolkodás néhány alapkérdésén, valamint a szervezeti döntések megalapozásán és a teljesítmény mérésén túl külön foglalkoztunk a kontrolling használatának lehetőségeivel is a szociális szféra vezetői számára.

\section{Kontrolling mint eszköz a vezetök kezében}

A modul során megismerhető közgazdaságtani, a szervezeti teljesítménnyel, illetve a hatékonysággal összefüggő fogalmak és törvényszerüségek elsajátítása önmagában is segíti a képzésben részt vevő vezetöket az intézményeik és szolgáltatásaik müködésének mélyebb megértésében, ugyanakkor fontosnak tartottuk, hogy egy, az ismeretek gyakorlati felhasználását segítő eszköz (kontrolling rendszer) is megismertetésre kerüljön a modul részeként.

A kontrolling szociális ágazatban történő alkalmazása jelenleg nem jogszabályi követelmény, bár egyes fenntartók már alkalmaznak kontrolling rendszereket, mégis a „pénzért értéket” szemléletmód ágazatban történő erősítése érdekében kiemelt jelentőségűnek ítéltük annak bemutatását, hogy egy jól kialakított kontrolling rendszer milyen módon és mértékben képes támogatni a vezetőket az intézményi müködéssel összefüggő döntéseik meghozatalában, valamint a szervezet és a szolgáltatások teljesítményének értékelésében. A vezetők részére a müködés teljesítményének értékelését és a folyamatok átlátását segítő kontrolling szerepe különösen fontos a szociális ágazatban, amelyben az intézmények által biztosított szolgáltatásokkal szemben támasztott elvárások rendkívül összetettek a különböző érintettek (az állam, a fenntartó, az ellátottak, illetve hozzátartozóik, beszállítók) részéről.

A képzésben részt vevők megismerhetik, hogy a kontrolling, amely elsősorban a gazdálkodási adatokból indul ki, nem kizárólag az intézmények szigorúan vett pénzügyi müködésének eredményességére terjedhet ki, hanem a különböző indikátorok és mutatószámok segítségével, a számok mögött megvalósuló szociális szolgáltatások teljesítménye, illetve a teljesítmények időbeli alakulása is mérhetô. A kontrolling tevékenység egyik legszembetünőbb hozzáadott értéke, hogy a vezetők az intézmények müködéséről nem az 
egyes költségvetési évek lezárultával kapnak átfogó képet, hanem folyamatosan nyomon követhetik a szolgáltatások minőségének alakulását, a költségvetés évközi teljesülését, valamint jóval korábban érzékelhetik az intézménymüködés során felmerülő problémákat.

A modul keretében az intézményvezetőket, az ágazatból vett példák és a már kialakult gyakorlatok alapján, az intézményvezetőket végigvezetjük a tervezés, az eltéréselemzés, illetve a beavatkozások tervezésével összefüggő, a modul vezérfonalát képező gazdasági döntések sorozata modellel jól illeszkedő kontrolling funkciókon. A funkciók áttekintésekor a vezetők megbizonyosodhatnak arra vonatkozóan, hogy egy kontrolling rendszer müködése jelentősen segítheti munkájukat, ugyanakkor mindez csak abban az esetben valósulhat meg, amennyiben egy a vezető elvárásai és az intézmény müködései sajátosságai alapján meghatározott, személyre szabott rendszer kerül kialakításra.

A kontrolling eszköztár alkalmazásával a szociális ágazatban tevékenykedő vezetők esetén erösödhet a cél- és jövőorientált szemléletmód érvényesülése a döntési bizonytalanság csökkenésével, valamint egy folyamatos, átfogó érzékelés alakulhat ki az irányított szervezetek teljesítményének állapotával összefüggésben.

\section{Tudásátadás a Szociális Vezetőképzésben}

A Szociális Vezetőképzés céljául tüzte ki a vezetői szemléletformálást a szociális ágazatban. A szociális szolgáltatók müködési környezete modul oktatási módszertana is ezt a szemléletformáló megközelítést támogatja. Interaktív módon, játékosan adja át a vezetők számára azt a hasznos tudást, melyet a vezető későbbi munkája során hasznosíthat döntései során. Véleménykvízek, illetve oktatóvideókon keresztül vezeti be a modul a különböző közgazdasági alapfogalmakat (melyekkel a vezetők életük során már biztosan találkoztak, akár otthon a családi környezetükben), mivel döntéseket egész életünk során kellett és kell majd még hozniuk. A vezetőképzés során ezen gazdasági ismereteiket rendszerezve, logikailag felépítve egy másik, új nézőpontból rátekintve bővíthetik tudásukat, így fejlesztve a vezetők közgazdasági gondolkodásmódját, mely segítségükre lehet vezetői munkájuk során, hogy teljeskörübb és jobb döntéseket tudjon hozni a későbbi munkájuk során, így fejlesztve az ágazaton.

A modul felépítése és ismeretanyaga úgy lett kialakítva, hogy az itt szerzett ismereteket, a vezető saját szervezetének, intézményének irányítása során a későbbiekben fel tudja majd használni. Tudásuk hasznos ismeretekkel, eszközökkel bővül, melyek hasznosíthatnak saját szervezetük müködésének jobb megismerésében és feltérképezésében. Ez alapján innovatívan fejleszthetik tovább szervezetüket, illetve javíthatnak a szolgáltatások minőségén, melyek megvalósulását hatékonysági mutatók bevezetésével ellenőrizhetik, illetve döntéseiket is ez alapján tudják értékelni, így megalapozva a következő döntési helyzetnél egy még jobb, még hatékonyabb döntés megszületését.

\section{Menedzsmentismeretek a szociális vezetőképzésben}

A Vezetés és szervezés modul a képzési programjában a vezetéstudomány elméleti ismereteinek bázisán olyan gyakorlatban is hasznositható tudást kíván átadni, amelyek segítik a résztvevőket mindennapos vezetői munkájuk során, pótolják hiányzó és bővítik meglévő vezetői ismereteiket. A képzés az ismereteknek nem pusztán az átadását, hanem elmélyítését is célul tüzi ki. A szituációs elmélet bázisán azt képviseljük, hogy a szervezetek esetében a különböző adottságoknak köszönhetően több lehetséges megoldás is létezik adott probléma kezelésére. Ebben a szemléletben ismertetjük meg a vezetőkkel az egyes 
menedzsmentmodelleket mint lehetséges, adaptálható eszközöket. Célunk egyfajta szemléletformálás, amely hozzájárul a közös értelmezési keret kialakításához, a rendszerszintü gondolkodás fejlesztéséhez, támogatva ezáltal a szociális szolgáltatások szakszerü szervezését, irányítását. Új perspektívákat is meg kívánunk nyitni a szociális intézmények irányításában: bemutatunk nemzetközi jó gyakorlatokat, vizsgáljuk ezek hazai adaptációs lehetőségeit, megismerjük a hazai innovatív megoldásokat. Inspirációt kívánunk nyújtani a vezetői munkához azzal is, hogy olyan oktatásmódszertani eszközöket használunk, amelyek alkalmasak a résztvevők érdeklődésének felkeltésére a stratégiai vezetés, a szervezés, illetve a szervezeti magatartás témái, technikái iránt. Közösen gondolkodunk vezetői kihívásokról, dilemmákról, a problémák megoldási lehetőségeiről konkrét helyzeteket és valós feladatokat felhasználva. A résztvevők az órákon számos csoportfeladatot kapnak, amelyek oktatói segítséggel megmutathatják, hogy miként oldjanak meg szakmaspecifikus vezetői problémákat. Az órákon video-esettanulmányokkal, filmrészletekkel színesítjük az oktatásmódszertani eszköztárunkat, amelyek a résztvevők visszajelzései alapján valódi segítséget jelentenek a tanulási, fejlesztési folyamatban.

Szándékaink szerint oktatási programunk a résztvevők számára egyfajta megerősítést is jelent, segíti a vezetői szerep tudatosítását, az önreflexió elmélyítését, hozzájárul régóta mélyülő feszültségek feloldásához, új kihívások azonosításához. A modul képzési programjának hosszabb távú hatásaként azt várjuk, hogy a részt vevő vezetők internalizálják az innovációk keresésének és megvalósításának igényét, keressék a kooperáció lehetőségét szervezeti szinten, ágazaton belül és ágazatok között egyaránt, ezáltal összességében is erősödjön az ágazat intézményeinek beágyazottsága, hálózati kapcsolatrendszere.

\section{Vezetöi kihívások a Vezetés és szervezés modul tantárgyainak tükrében}

A modul három szakmai blokkból áll. Ezek a stratégiai vezetés, a szervezés, valamint a szervezeti magatartás. Mindegyik 12 órából, alapvetően egymást követő, egymásra épülő kétkét oktatási napból áll. A szervezeti magatartás blokk két oktatási napja között több oktatási hét is eltelik, amely lehetővé teszi, hogy az ágazati és finanszírozási ismereti tárgyak során szerzett tapasztalatokra is építhessünk. A modul első oktatási napján a résztvevőkkel megismertetjük a vezetői munka néhány kiinduló, legfontosabb keretét (vezetési funkciók, vezetői szerepek, vezetési stílus alapmodelljei segítségével), hogy már a közös munka kezdetén kialakíthassák saját munkájuk perspektívájából viszonyulásukat, megfogalmazhassák várakozásaikat a modul témái iránt.

\section{Stratégiai vezetés}

A stratégiai vezetés keretében a szervezet hosszú távú müködését jelentősen meghatározó vezetői funkcióval, a célok kijelölésével és stratégiaalkotással foglalkozunk, valamint tárgyaljuk a stratégiai emberierőforrás-menedzsment (HR) főbb területeit, illetve a minőségirányítás szerepét a szociális területen müködő szervezetek irányításában. A résztvevőkkel közösen gondoljuk végig a szervezeti szintű stratégia lehetséges szerepét, kialakításának előnyeit és nehézségeit, a hosszú távú célok és elvárások megfogalmazásának lehetőségeit és jelentőségét. A közszféra foglalkoztatási rendszereinek és az emberierőforrásmenedzsment részterületeinek megismerése a munkatársak irányításával kapcsolatos vezetői feladatok értelmezéséhez és keretezéséhez járul hozzá. A képzés során áttekintjük az emberierőforrás-menedzsment részterületeit és a kapcsolódó vezetői feladatokat. A minőségirányítás a szociális ellátás folyamatára, eredményére, valamint az ügyfelek elvárásaira is fókuszáló mérési, értékelési eszköztárat nyújt a vezetők számára, amely a szolgáltatástervezési és -fejlesztési feladatokhoz jelent támogatást. 
A szociális szférára adaptált vezetéstudományi oktatás szembe kell nézzen kihívásokkal, dilemmákkal is, annak a kérdésnek a mentén, hogy az alapvetően az üzleti szféra gyakorlatából kiinduló és profitorientált szervezetek esetében alkalmazott megoldások, modellek adaptálhatók-e a közfeladatokat ellátó, nem profitorientált szervezetek számára is. Az elmúlt évtizedekben számos példát láttunk különböző üzleti módszertanok sikeres alkalmazására közszektorbeli szervezetekben, ilyenek például a különböző stratégiaalkotási technikák (például SWOT-elemzés) vagy minőségirányítási eszközök (Total Quality Management, TQM) terjedése. Ugyanakkor a közfeladatokat ellátó intézmények többsége sajátos jellemzőkkel bír az üzleti szervezetekhez képest, gondoljunk csak a vevő fogalmának többértelmüségére vagy a politikai és jogi racionalitás jelenlétére. Mindezek alapján körültekintő megközelítés javasolt az üzleti modellek, módszertanok alkalmazásakor, azaz az egyes módszertanok gondos kiválasztása, szürése, megfelelö adaptálása, átdolgozása és tesztelése szükséges a sikerességhez (Antal et al. 2011).

A stratégiai vezetés keretében tárgyalt tématerületeket illetően számos izgalmas kérdés, vezetői dilemma merült fel az eddigi képzések során, amelyeken a résztvevőkkel közösen gondolkodva keressük a válaszokat és térképezzük fel a szektorban jelenlévő jó gyakorlatokat. A stratégiaalkotás kapcsán fontos dilemma, hogy mekkora a mozgástér a szociális ágazatban a hosszú távú célok kijelölése és a stratégiák kialakítása során az egyes szervezetek vezetőinek szintjén:

- Mi az az időtáv, amelyre érdemes tervezni?

- Mi a jogszabályok szerepe a hosszú és középtávú tervezés során?

- Mi a stratégia jelentősége a napi, operatív müködés tervezésében?

- Mely tényezők ösztönzik és melyek akadályozzák a stratégiai tervezést a szektorban?

A stratégiai vezetés keretében nagy hangsúlyt fektetünk továbbá az egyik legfontosabb stratégiai erőforrás, a szervezetben dolgozó munkatársakkal kapcsolatos vezetői feladatok értelmezésére. A szervezetekben a stratégiai emberierőforrás-menedzsment foglalja keretbe ezeket a feladatokat, amely az emberierőforrás-folyamatok és rendszerek integrált tervezését, müködtetését, értékelését és fejlesztését jelenti azzal a céllal, hogy támogassa a szervezet stratégiájának megvalósítását (Bakacsi et al. 2004).

A leggyakoribb dilemmákat az egyes HR-részterületeket illetően az alábbiakban foglaljuk össze:

- A munkavégzési rendszerek kapcsán a munkafeladatok definiálásával, a munkakörök kialakításának lehetőségeivel foglalkozunk. Fontos kérdés, hogy a képzettségen túl milyen szempontokat érdemes figyelembe venni a munkakörök kialakításánál, átalakításánál. Mit is jelent és mire jó a munkakör-gazdagítás? Milyen lehetőségei vannak a rugalmas munkarendnek, illetve a részmunkaidős megoldásoknak?

- Az emberierőforrás-áramlás a szervezetbe való bekerüléssel, a karriermenedzsmenttel és a kiáramlással kapcsolatos HR-tevékenységeket foglalja össze. E terület kapcsán fontos felvetés, hogy az ágazat egyes területein jellemző munkaerőhiány esetén hogyan lehet jó munkatársakat találni és megtartani őket. Milyen toborzási csatornák váltak be? Milyen eszközei vannak a vezetőnek a motiválatlan és/vagy alkalmatlan munkatársakkal kapcsolatos kihívások kezelésére?

- A javadalmazási és kompenzációs rendszerek a munkavégzésért kapott anyagi és nem anyagi jellegü ellenszolgáltatásokkal kapcsolatos HR-feladatokat foglalják keretbe. E 
részterület esetén gyakori kérdésként fogalmazódott meg a képzés során, hogy milyen javadalmazási és nem anyagi kompenzációs eszközöket alkalmaznak a szociális ágazatban? Amennyiben korlátosak az anyagi lehetőségek, milyen egyéb módon ösztönözhetők a munkatársak?

- A képzési és fejlesztési feladatok egy szintén fontos HR-területet jelentenek. Ennek kapcsán az egyik fö kérdést az jelentette, hogy hogyan illeszthető ez a HR-feladat a több emberierőforrással kapcsolatos részrendszerhez. Dilemmaként jelentkezett továbbá, hogy miképp is azonosíthatók a képzési-fejlesztési szükségletek.

- Az egyéni teljesitménymérés és -értékelés célja az egyéni teljesítmény és a szervezeti célok közötti összhang megteremtése. Az eddigi képzések során az rajzolódott ki, hogy ezen HR-részterület nem elterjedt a szociális szféra szervezeteiben, de léteznek jó gyakorlatok. Kérdésként merült fel, hogy milyen céllal érdemes egyéni szintü teljesítménymérést és -értékelést alkalmazni. Hogyan kapcsolódik ez a terület a többi HR-részrendszerhez? Miképp mérhető egy dolgozó teljesítménye? És mire használható ez az információ?

A stratégiai vezetés tantárgy harmadik fókuszterülete a minőségirányitás. Itt tisztázandó kérdés, hogy mit jelent a minőség és ki is definiálja azt a szociális ellátások esetében. Milyen vevői szerepek vannak, és ki tekinthető vevőnek a szociális szolgáltatások esetében? Hogyan mérhető a szociális ellátás hatása, és milyen mérési eszközök léteznek?

\section{Szervezés, szervezetalakitás}

A szervezeti célok sikeres megvalósítását több vezetői eszközzel lehet segíteni. Ezek egyike a vezetők által kialakított, müködtetett formális szervezeti struktúra. A rosszul kialakított és müködtetett modell olyan, mint egy szük ruha: kényelmetlen, korlátozó, diszkomfortos. Szervezeti kontextusban értelmezve ezt: sok konfliktust generál, bizonytalanságot szül, gátolja az együttmüködést, a döntések halogatására és a problémák áthárítására ösztönzi a munkatársakat.

A képzés során elsőként abban segítjük a vezetőket, hogy felismerjék a szervezeti struktúra meghatározó szerepét a müködésükben. Ezt követően pedig abban, hogy a leginkább megfelelö, vagyis adekvát modellt tudják kiválasztani szervezetük számára, amely a szervezeti célok megvalósítását, az alapfeladatok ellátását megfelelően tudja majd támogatni. Célunk az is, hogy felkészítsük a vezetőket az egyes szervezeti formák sajátosságaiból adódó várható nehézségekre és kezelésük lehetséges módjaira. A megfelelő modell kiválasztása utáni legnagyobb kihívás az, hogy hogyan lehet a leginkább célszerüen, az adott forma belső logikájának megfelelő, harmonikus, ellentmondásoktól mentes müködést megtervezni, fenntartani. Gyakran tapasztalható, hogy a munkatársak közötti konfliktus oka szervezeti: nincsenek jól elhatárolva a feladatok az egységek között, hiányzik a felelőse egy-egy tevékenységnek, olyan teljesítményért teszünk felelössé vezetőket, amit semmilyen módon nem tudnak befolyásolni.

Az üzleti szervezetekben is nagy kihívás a szervezeti folyamatok azonosítása és folyamatos javítása. A folyamatszervezés során a középpontban az ügyfél igényeinek kell állnia. A jól kialakított folyamatokban minden közremüködő jól tudja a feladatát, kiszámíthatóan és tervezetten történnek az események, az erőforrások felhasználása célszerüen történik, és minden közremüködö ügyfélnek érezheti magát. Fontosnak tartjuk, hogy ez a fajta szemlélet erőteljesen jelenjen meg a szociális vezetői munkában, megmutassuk azokat az eszközöket (különösen a digitalizáció adta lehetőségeket), amelyek a folyamatok azonosításában és optimalizálásában felhasználhatók. Ennek illusztrálására a szociális munka speciális 
megoldását, az esetmenedzseri rendszer lehetséges értelmezéseit és szervezeti megoldásait is felhasználjuk.

Az egyéni munkakörök kialakítása, tervezése a szervezési munka utolsó lépése, amely a leglátványosabban kapcsolódik a HR-tevékenységhez és a személyes vezetéshez. Inputot szolgáltat a toborzási tevékenységhez, alapját képezheti az ösztönzési rendszernek, segíthet az egyéni fejlesztésben, teljesítményértékelésben.

A szervezeti struktúra és folyamatok alakítása olyan változásokat indíthat el, amelyek újabb feszültségeket, konfliktusokat hozhatnak a szervezet életébe. A szervezeti ellenállások kezelése a változtatási folyamat egyik kiemelt területe. Felfogásunk szerint, ha a hétköznapok vezetői munkájában meg tudjuk erősíteni a felső vezetőket, akkor sokat tettünk azért, hogy a változások, illetve a projektek irányításában is tudatossabbá, magabiztosabbá tegyük őket (Dobák, Antal 2016).

Mesterképzésünk eddigi tapasztalatai alapján a szervezés tárgy fókuszában álló legfontosabb vezetői dilemmák a következők:

- Lehet-e az üzleti modelleket adaptálni a szociális szférára, vannak-e speciális megoldások?

- Van-e egyáltalán mozgástere a vezetőknek az erős szabályozási környezetben?

- Hogyan lehet jól kezelni a centralizációt szervezeten belül és a nagy állami vállalat-, és intézménycsoportokban?

- Jelenthet-e megoldást a szervezetalakítás, szervezés a HR-krízisre?

- Hogyan kezelhető a perszonálunió a szervezetekben, milyen nehézségeket okoz a szervezeti müködésben?

- Hogyan állítható a szervezet müködésének fókuszába az ügyfél, ehhez hogyan használhatók a digitalizálás eszközei?

- Milyen eszközei vannak a belső együttmüködés támogatásának, és ebben milyen szerepe van a szabályzatoknak, szabályozásnak, illetve hogyan lehet értelmesen szabályozni a szociális szervezetekben?

- Izgalmas kérdés az is, hogy a munkaszervezés eszközei hogyan köthetőek a motivációhoz, valamint a szervezés minősége hogyan hat a szervezet teljesítményére?

\section{Szervezeti magatartás}

A tantárgy a szervezeten belüli magatartás egyéni, csoportos és szervezeti szintü jelenségeit, összefüggéseit mutatja be felső vezetői perspektívából. A képzés során jelentős hangsúlyt kap a személyes vezetés, vagyis annak ,tudománya”, hogy a vezető munkatársait a szervezeti célok érdekében hogyan tudja közvetlenül mozgósítani. Célunk, hogy a résztvevők vezetői munkájuk során mélyebben értsék az egyéni motivációkat, reakciókat, e tudást eredményesen tudják felhasználni a szervezeti célok teljesítése érdekében, és segíteni tudják munkatársaik szervezeten belüli ,jóllétét”, fejlődését. A 21. század régi és új kihívásokkal szembesíti a vezetőket, így a szervezeti magatartás (organizational behavior, OB) tárgykörébe tartozó eredmények gyakorlati megismerése és felhasználása a vezetői munkában a változásokhoz való alkalmazkodás fontos eszköze (Bakacsi 2015; Heath et al. 2001; Robbins et al. 2012).

A szervezeti magatartás tárgy keretében nagy hangsúlyt fektetünk olyan vezetői helyzetek és kihívások elemzésére, amelyek rávilágítanak az egyéni készségek, értékek, hiedelmek 
szerepére a munkatársak kiválasztásában és a munkavégzésben, valamint a munkával kapcsolatos motivációra. A képzés során a résztvevők tudatosíthatják a vezető felé a különböző elvárásokat támasztó szerepeket, megvitathatják az eredményesen alkalmazható vezetési stílusok jellemzőit, alkalmazásuk feltételeit. Mindez lehetőséget biztosít arra, hogy saját vezetői tevékenységükre, stílusukra egy új perspektívából is rátekintsenek, valamint bővítsék vezetői eszköztárukat. A tárgyalt témák között szerepel a szervezeti klíma és a szervezeti kultúra, amelynek befolyásolása gyakran jelent vezetői kihívást, különösen olyankor, amikor a vezető szervezeti változásokat kezdeményez vagy a környezeti változások hatására változtatásra kényszerül. A képzés segíteni kívánja az egyéni és szervezeti szintü változások irányában és ellenében ható tényezők megértését, a változások vezetését és a változáshoz kapcsolódó ellenállás kezelését is. A munkahelyi stresszel a kihívásokhoz való alkalmazkodás képességével (reziliencia) és a munkatársak felhatalmazásával (empowerment) kapcsolatos ismeretek pedig a munkatársak pszichoszociális támogatását, fejlesztését is szolgálják.

A hatékony szervezeti teljesítmény szempontjából az emberekkel, munkatársakkal való kapcsolat, a befolyásolás képessége, a közvetlen irányítás szerepe kiemelt jelentőségü a vezetői munkában. A mindennapok emberi interakcióiban a vezetők részéröl is természetesek az ösztönös reakciók, emellett elsősorban a nehezebb helyzetekböl, eredményesen vagy kevésbé sikeresen megoldott problémákból származó tapasztalatokból is képződik egy eszköztár. A képzés eddigi tapasztalatai alapján a szociális ágazatban dolgozó vezetők körében is rendszeresen akadnak olyan, egy-egy munkatárshoz vagy munkatársak csoportjához kapcsolódó helyzetek, amelyek kezelése hosszabb időt, komolyabb fejtörést, tudatos akciókat igényel.

A vezetők a tantárgy témái kapcsán is hangsúlyosan megjelenítették, hogy az ágazat számos intézménye humánerőforrás-problémákkal szembesül. Sok a betöltetlen álláshely, a meghirdetett helyek egy részére nehezen akad megfelelő szakmai felkészültségü és elkötelezettségü jelentkező, és olykor a tapasztalt, magas színvonalú szakmai munkát végző kollégák megtartása is kihívást jelent.

Nehéz szembesülni azzal, hogy a munkával kapcsolatos motiváció a vezető számára adottság, a vezető eszközei elsősorban arra terjednek ki, hogy - akár egyénre szabottan - olyan feladatokat, feltételeket biztosítson, amelyek a munkatársak motivációihoz illeszkednek. Az anyagi lehetőségek korlátozottságát az ágazatban a vezetők gyakran jelentős akadályként említik. Leggyakrabban tapasztalt dilemmájuk, hogy megfelelö fizetés nélkül lehet-e motiválni a munkatársakat, milyen további eszközök állnak ehhez rendelkezésükre, és vajon meddig tartanak ki azok az értékek, amelyek valakit a szociális ágazatban végzett munkára, a segítő hivatásra késztetnek. ${ }^{4}$

A szociális ágazatban dolgozó felső vezetők munkájában a szervezeti magatartás témaköreihez kapcsolódóan az alábbi, további dilemmák is jelentkeznek:

- Hogyan kezelhetők azok a munkatársak, akiknek sem a szakmai felkészültsége, sem a motiváltsága nem megfelelö? Mennyi energiát szánjon a vezető az ösztönzésükre? Mit lehet tenni, ha sem szervezeten belül, sem kívül nincsen megfelelő utánpótlás?

\footnotetext{
${ }^{4}$ Nemzetközi vizsgálati eredmények szerint a vezetői interperszonális készségeknek és érzelmi intelligenciának kiemelt szerepe van az eredményes vezetésben (Riggio et el. 2003; Zaccaro 2002; Humphrey et al. 2007), a hatékony együttmüködésben, sikeres alkalmazásuk pedig pozitívan hat a szervezeti klímára és az üzleti teljesítményre (Goleman2000).
} 
- Hogyan segíthetök azok a kulcsemberek, akikre jelentős többletfeladat hárul? Hogyan találja meg az egyensúlyt a vezető a „terhelésükben” és a támogatásukban?

- Milyen vezetői eszközökkel kezelhető a segitő foglalkozásból adódó lelki megterhelés? Mit tehet a vezető a kiégés megelőzésére?

- Milyen kevés anyagi ráfordítással járó eszközöket alkalmazhat a vezető az innovatív szemlélet kialakítására, a munkahelyi légkör javítására, az elégedettség növelésére? Lehet-e létjogosultsága az ágazatban a rugalmas munkaidőnek, a távmunkának, az innovációra, fejlesztésre dedikált külön időkeretnek?

- Milyen tudatos lépésekkel, akár személyi döntésekkel tudja segíteni a vezető a kultúraváltást?

- Hogyan kezelje a vezetö az intézményi és szabályozási környezet dinamikus változását, különös tekintettel az intézmények szétválására, összeolvadására? Hogyan kommunikáljon a vezetö, hogy ilyen helyzetekben végig hiteles és támogató maradjon a munkatársak és a fenntartó irányába is?

\section{Oktatási tapasztalataink}

Eddigi tapasztalataink alapján úgy tünik, hogy a modul témái tekintetében rengeteg a vezetői tapasztalat (siker és kudarc egyaránt), de jelentősen fejleszthető a vezetői ismeretek tudatos alkalmazásán alapuló problémamegoldás. A képzés során elsajátítható tudás, megismerhető szemlélet, új energiák a szervezeti jelenségek és problémák gyorsabb, pontosabb, reálisabb azonosításában tudnak segíteni a részt vevő vezetőknek. Egy-egy szituáció megbeszélése, elméleti keretek közé helyezése sok esetben okozott a vezetöknek „aha élményt”, rávilágítva arra, hogy egy alkalmazott megoldás miért müködött jól vagy éppen miért nem volt sikeres. Azzal is gyakran szembesültünk, hogy a vezetők szük mozgásteret látnak a változtatásra: a külső körülményeket, jogszabályi kereteket feloldhatatlanul masszív korlátként élik meg, de a belső adottságok, leginkább a humán erőforrások tekintetében is küzdenek démonaikkal. Nem az a célunk, hogy a pesszimizmust optimizmusra váltsuk át, hanem az a törekvésünk, hogy a lehetőségek és korlátok reális felismerésében adjunk támogatást, és inspiráljuk a résztvevőket a nyitottságra, az innovációs lehetőségek, a jó nemzetközi és hazai gyakorlatok megismerésére.

\section{Menedzsmentkészségek és kompetenciák fejlesztése a szociális vezetőképzésben}

A szociális, gyermekjóléti és gyermekvédelmi közszolgáltatást végző intézmények müködésének egyik legfontosabb alapelve a személyes gondoskodás, melynek lényege, hogy az ellátott a lehetőségekhez mérten a neki legmegfelelöbb szolgáltatást és támogatást kapja az ágazatban dolgozó szakemberek részéről. Ennek a megközelítésnek a fókuszában az ellátott egyén áll, a személyes jelleg azonban csak részben vonatkozik rá. A személyes gondoskodás nemcsak a segítségnyújtás személyre szabottságát jelenti, hanem azt is, hogy a gondoskodás mögött személyek állnak, olyan vezetők és dolgozók, akik saját személyiségükkel végzik munkájukat. A Semmelweis Egyetemen 2018 öszén indult kétszintủ szociális vezetőképzés egyik fontos célkitüzése a személyes gondoskodás ilyen jellegủ értelmezése, amelyet a képzés úgy kíván megvalósítani, hogy a szakmai feladatok irányításához szükséges elmélyült, korszerü ismeretek megszerzésén túl kiemelt figyelmet fordít nemcsak a vezetői kompetenciák elmélyítésére, hanem magára a vezető személyére is. Ez az alapelv a teljes 
képzési programban vörös fonalként megfigyelhető, de kiemelt jelentőséget kap a Menedzsmentkészségek és kompetenciák alkalmazása a gyakorlatban elnevezésü modul tréningjellegü oktatásában.

Mielőtt bemutatásra kerülnek a modul stúdiumai, még két fontos alapelvet kell megfogalmaznunk. A vezető legfontosabb munkaeszköze saját személyisége. Személyiségével kapcsolódik a dolgozókhoz és az ellátottakhoz, és a személyiségével tud megfelelö intervenciókat eszközölni. Mindezt nem a szükséges szakmai ismeretek ellenében fogalmazzuk meg, hanem éppen azok minél hatékonyabb alkalmazása érdekében. Egy-egy segítői intervenciót csak részben lehet leírni az ágazati dolgozó és ellátott fogalompárral, vagy éppen a segítő és segített kifejezésekkel. Ezekben a szakmai interperszonális kapcsolatokban egyidejüleg két személy, két ember is találkozik. Erre a kapcsolódásra vagy éppen annak nehézségeire is elengedhetetlen figyelmet fordítani.

Ebből az alapelvből egyenesen következik, hogy a tananyag gerincét nem az új lexikális ismeretek adják. A mindennapi tapasztalatokból felvetődő kérdésekre, dilemmákra vagy elakadásokra elsősorban a hallgatók már meglévő tapasztalataiból és ismereteiből kívánunk válaszokat megfogalmazni, vagy ha szükséges, további kérdéseket feltenni. A tapasztalati, reflektív tanulási módszert részesítjük előnyben.

Izgalmas kérdésként vetődhet fel, hogy lehet-e egyáltalán bármilyen változást elérni évtizedek alatt begyakorolt vezetői müködésekben? Ez minden felnőttképzés komoly kihívása. A modul célja elsősorban nem az egyes vezetői technikák megváltoztatása, hanem sokkal inkább egy szemlélet átadása, melynek középpontjában a vezető személyisége áll, aki a vezetői intervenciókra a szakmai szinten túl a mélyebb interperszonális szinteken is képes reflektálni, és amennyiben szükséges, új intervenciókat alkalmazni.

\section{A 4. modul felépitése}

A 2018 tavaszán jóváhagyott kétszintü szociális vezetőképzés programja alapján a Menedzsmentkészségek és kompetenciák alkalmazása a gyakorlatban elnevezésű modul négy stúdiumból áll: szervezeti magatartás, kommunikáció a szervezetben, konfliktuskezelés a szervezetben, valamint szervezeti mentálhigiéné és a kiégés megelőzése. A pilotoktatás elökészítése során célszerübbnek mutatkozott az oktatási blokkokat úgy felépíteni, hogy a szervezeti magatartás címü stúdium szorosabban kapcsolódjon a III. modul, azaz a Vezetés és szervezés tantárgyaihoz. Ennek értelmében itt csak három stúdium kerül bemutatásra.

\section{Kommunikáció a szervezetben}

Az egyik legizgalmasabb és legfontosabb vezetői feladat a kommunikáció. Szervezeten belül és kívül kiemelt jelentőséggel bír, hogy a megfelelö üzenetek eljussanak a munkatársakhoz, partnerekhez és a szolgáltatást igénybe vevőkhöz. A szociális intézmény vezetőjének tudatos és egyértelmü kommunikációja nagymértékben hozzájárul a szervezet hatékonyságához.

A tárgy célja, hogy a hallgatók rálássanak saját kommunikációs erősségeikre és fejlesztendő területeikre, valamint hogy megismerjék a szervezeti kommunikáció elméleti alapjait. A tárgy keretében elemezzük a szervezet kommunikációs rendszerét, a kommunikációs folyamatot nehezítő akadályokat, valamint a szituációhoz igazodó, hatékony kommunikációs stratégiákat. A hallgatók saját szervezeteikre reflektálva tárgyaljuk a formális és informális kommunikációs utakat, a vertikális és horizontális csatornákat, valamint ezek specialitásait. Többféle kommunikációs típus feltárása révén a tárgy segíti a hallgatókat az írásos és verbális kommunikáció meggyőző és hatékony használatában. Kitérünk a különböző kommunikációs stílusok (agresszív, passzív, asszertív) sajátosságaira és a másokat bevonó, támogató és ösztönző kommunikációs elemek fontosságára. 
A legtöbb szervezet kommunikációs rendszerében központi helyet kapnak a különböző teammegbeszélések, értekezletek, azért kitérünk a hatékony értekezlet vezetését segító és akadályozó tényezőkre. Ezentúl foglalkozunk a nyilvános beszéd és prezentáció szerepével, segítve a résztvevőket előadói készségük fejlesztésében.

A tárgy során a hallgatók számára lehetőség nyílik a tudatos kommunikáció páros és kiscsoportos gyakorlására és a visszajelzések mentén történő továbbfejlődésre.

\section{Konfliktuskezelés a szervezetben}

A tárgy célja a szervezet életében előforduló konfliktusok felismerésének, elemzésének és tudatos kezelésének fejlesztése. Vezetőként kiemelten fontos készség, hogy milyen konfliktusok esetén és hogyan avatkozunk be a konfliktusok lefolyásába. Munkahelyi konfliktusok esetén gyakran nem zéröösszegü helyzetről van szó, mégis a résztvevők ilyen hozzáállással vannak jelen. A tárgy keretében tárgyaljuk a destruktív-konstruktív konfliktusok sajátosságait és a konstruktív folyamatba való fordítás lehetőségeit, az utakat a győztesvesztes helyzetektől a győztes-győztes szituációkhoz.

A tárgy célja továbbá a munkahelyi konfliktusok több szempontú elemzése. Esettanulmányok segítségével vizsgáljuk a különböző konfliktusforrások specialitásait, a konfliktus eszkalációját (Glasl modellje) és különböző fokozatait. A konfliktusok kezelésének informális és formális módozatait tárgyalva keressük a munkahelyi konfliktusokra adható válaszokat és az optimális megoldási lehetőségeket.

A munkahelyi konfliktusok többsége informális megbeszéléssel vagy közvetlen tárgyalással rendezhetö, ezért különös hangsúlyt helyezünk a tárgyalás formáira és a hatékony tárgyalás feltételeire. Ennek keretében olyan kérdéseket érintünk, hogy miként válasszuk le a személyt a problémáról; hogyan összpontosítsunk a szükségletekre és érdekekre a pozíciók helyett; hogyan müködjünk együtt a másik féllel a kölcsönösen kielégítő megoldás elérése érdekében.

A résztvevők a kurzus során tudatosítják egyéni konfliktuskezelési sémáikat, erősségeiket és fejlesztendő területeiket a konfliktuskezelésben és a tárgyalásban.

Szervezeti mentálhigiéné, a kiégés megelözése

A tantárgy célja egy olyan mentálhigiénés szemlélet elsajátítása, amelynek segítségével a vezető beosztású személy differenciáltabban tudja kezelni a szervezet mikro-, mezo- és makroszintű változásait, valamint olyan prevenciós intervenciók megtervezésére válik képessé, amelyek a szervezet egészséges müködését, valamint a munkahelyi közérzetet pozitív irányba tudják elmozdítani.

A szociális területen müködő szervezetek dolgozóit fokozottan érinti az érzelmi megterhelés, ezért a kiégés kockázata is hangsúlyosabban jelenik meg, mint sok más szférában. A különböző stresszorok és a munkahelyi stressz egyéni és szervezeti szintü következményeivel találkozva sokszor eszköztelennek érzi magát a vezető. A tárgy keretében közösen keressük azokat a módszereket, technikákat, melyek egyéni, vezetői és szervezeti szinten hozzájárulhatnak a kollégák mentálhigiéjének növeléséhez.

A szituációs gyakorlatok és esettanulmányok feldolgozásával bemutatásra kerülnek olyan mentálhigiénés intervenciók, amelyek révén hatékonyabbá válik az egyénekkel és csoportokkal (teamképesség) való együttmüködés, az emberi erőforrás tervezése, igazgatása és ellenőrzése. 
A promotív szemlélet elsajátításával a vezető képessé válik a kiégés folyamatának korai felismerésére, differenciált kezelésére. A társadalmi hatásokon és a munka jellegéből adódó megterhelésen túl a lelki egészséget meghatározó faktorokat is figyelembe veszi.

A tantárgy keretében bemutatásra kerülnek különböző kiégésszintmérési lehetőségek és adekvát intervenciós lehetőségek.

\section{A tantárgyak megjelenése a képzésben}

A kétszintü szociális vezetőképzés oktatási programja szerint a 4-es modul számára a mestervezetőképzésben 24 óra áll rendelkezésre (4 oktatási nap), az alap-vezetőképzésben pedig 6 óra (1 oktatási nap). A pilotképzés (mester-vezetőképzés) tanulsága szerint szükségesnek bizonyult az egész képzési folyamat elején egy 3 órás csoportkohéziós tréning, amely azt a célt szolgálja, hogy már a képzés elején olyan kapcsolatok szülessenek, amelyek a képzés során a csoportos, interaktív munkát elősegítik, hosszabb távon pedig a szakmai hálózatosságot alapozhatják meg.

A csoportkohéziós tréning során az ismerkedésen túl fontos szerepet kap annak feltérképezése is, hogy a hallgatók milyen jellegü intézményeket vezetnek, milyen vezetői dilemmákkal és kihívásokkal kell megküzdeniük, milyen elvárásokat támasztanak a vezetőképzéssel kapcsolatban, és mi az, amivel ők tudják gazdagítani a képzés folyamatát.

A 4. modul további témái a vezetőképzés utolsó képzési blokkjában kerülnek elő. Ennek időzítése arra is lehetőséget ad, hogy a korábbi modulok témái még inkább utat találjanak a gyakorlati megvalósulás irányába.

\section{Az oktatott tananyag relevanciája a célcsoport számára}

Ahogy korábban már megfogalmaztuk, a tananyag gerincét nem az új lexikális ismeretek adják, hanem a hallgatók mindennapi tapasztalataiból felvetődő kérdések és dilemmák. Ezek megjelenítése, majd a rájuk történő reflexió és bizonyos következtetések megfogalmazása az a folyamat, amely végigkíséri a 4. modul tréningjellegü oktatását (Kolb-féle tapasztalati tanulási modell). A célcsoport felöl megközelítve ez a tanulási modell biztosítja a tananyag relevanciáját. Ugyanakkor az oktatási program is megfogalmaz olyan kompetenciákat, amelyek leginkább a 4. modul oktatási blokkjában sajátíthatók el: a vezetési feladatok problémaközpontú megközelítése és a szervezeti döntéshozatali módszerek alkalmazása, konfliktusok kezelése, a beosztottak mentálhigiénés problémáinak felismerése és a kiégés megelözése, motivációs eszközök kidolgozása és alkalmazása, a vezetői funkciók hatékony gyakorlására megalapozó információs és kommunikációs rendszerek tervezése, alakítása és helyes használata. A modul oktatói számára izgalmas kihívást jelent a hallgatók tapasztalataiból kiinduló problémafelvetés és a kompetenciák elsajátításának együttes megközelítése.

\section{Eddigi oktatói tapasztalatok}

A szociális ágazatban tapasztalható konstans nehézségek, mint a forráshiány vagy éppen az utóbbi években egyre nagyobb problémát jelentő munkaerőhiány komoly megterhelést jelent az intézményvezetők számára. Legtöbbször ezekkel a kihívásokkal egyedül kell megküzdeniük. A vezetőképzés egyik kiemelt célja - és az eddigi tapasztalatok alapján fontos hozománya - a korszerü vezetői ismeretek átadásán túl, hogy lehetőséget biztosítson a hallgatók számára a problémák közös felvetésére, a jó gyakorlatok megosztására és a szorosabb ágazati együttmüködés kialakítására. Az eddigi oktatói tapasztalatok alapján ennek elősegítése és facilitálása fontos feladata a vezetőképzésnek. 
Ahhoz, hogy egy adott intézményben a vezető beosztású szakember minél inkább képviselni tudja a személyes gondoskodás alapelvét, egyrészt szüksége van saját személyiségének minél mélyebb megismerésére, szakmai ismereteinek és kompetenciáinak fejlesztésére, de arra is, hogy saját élménye legyen a személyes gondoskodásról. A szociális vezetőképzés 4. modulja ezt a tapasztalatot kívánja biztosítani a hallgatók számára.

\section{Összefoglalás}

A tavalyi évtől bevezetett szociális vezetőképzés lehetőséget teremt egy olyan modern szemléletet tükröző oktatási program megvalósítására, amely valós segítséget jelent az érintettek számára a mindennapi munkájukban. Bár a tanúsítvány megszerzése kötelező a résztvevők számára, mégis helyesebb lehetőségként tekinteni a programra. Különösen szerencsés helyzet, hogy az első időszakban európai uniós forrásból tud megvalósulni a képzés, így nem jelent pénzügyi terhet az intézményeknek. A képzési és oktatási program kidolgozásakor nagy figyelmet fordítottunk arra, hogy az illeszkedjen az érintettek igényeihez, ne csupán egy újabb papírral hagyják el a Semmelweis Egyetemet, de valós, használható tudással is gazdagodjanak. Karunknak az egészségügyi menedzserképzés során szerzett tapasztalatai megerősítették azt, amit az alapítók már két évtizeddel ezelőtt tudtak: nem elég a szakma magas szintü ismerete és az elkötelezettség. Az intézmények professzionális müködéséhez elengedhetetlenek a vezetői készségek és ismeretek. Egyetemünk névadójának, Semmelweis Ignácnak a személyes élettörténete és tragikus halála arra emlékeztet minket, hogy a magas szintű szakmai tudás néha kevés a sikerhez, ha nem párosul olyan menedzseri készségekkel, amelyek szükségesek a változások elfogadtatásához és a munkatársak fontos ügyekhez való megnyeréséhez. A Semmelweis Egyetem vezetőképzésével ezeknek a készségeknek a fejlesztéséhez szeretnénk hozzájárulni. Ehhez fontos segítséget nyújtanak a hallgatói értékelések és visszajelzések. A jelen tanulmányban ismertetett képzési anyag tehát korántsem tekinthető véglegesnek, folyamatosan felülvizsgáljuk azt, hogy minél inkább alkalmazkodjanak a változó igényekhez és a változó környezethez. 


\section{IRODALOMJEGYZÉK}

25/2017. (X. 18.) EMMI rendelet a vezetői megbízással rendelkező szociális szolgáltatást nyújtó személyek vezetőképzéséről

1993. évi III. törvény a szociális igazgatásról és szociális ellátásokról

ANTAL ZS., DRÓTOS GY., KISS N., KOVÁTS G., RÉVÉSZ É., VARGA-POLYÁK CS. (2011): Közszolgálati szervezetek vezetése. Budapesti Corvinus Egyetem Vezetéstudományi Intézet, Budapest.

BAKACSI GY., BOKOR A., CSÁSZÁR CS., GELEI A., KOVÁTS K., TAKÁCS S. (2004): Stratégiai emberi erőforrás menedzsment. Akadémiai Kiadó Zrt., Budapest.

BAKACSI GY. (2015): A szervezeti magatartás alapjai. Alaptankönyv Bachelor hallgatók számára. Semmelweis Kiadó, Budapest.

DOBÁK M., ANTAL ZS. (2016): Vezetés és szervezés. Akadémiai Kiadó, Budapest.

GOLEMAN, D. (2000): 'Leadership that gets results'. Harvard Business Review, 78(2). 7890 .

HEATH, C., SITKIN, S. B. (2001): Big-B versus Big-O: What is organizational about organizational behavior? Journal of Organizational Behavior, 22(1). 43-58.

HUMPHREY, S. E., NAHRGANG, J. D., MORGESON, F. P. (2007): Integrating Motivational, Social, and Contextual Work Design Features: A Meta-Analytic Summary and Theoretical Extension of the Work Design Literature. Journal of Applied Psychology, 92(5). $1332-1356$.

MINER, J. B. (2003): The rated importance, scientific validity, and practical usefulness of organizational behavior theories: A quantitative review. Academy of Management Learning \& Education, 2(3). 250-268.

RIGGIO, R. E., RIGGIO, H. R., SALINAS, C., COLE E. J. (2003): The role of social and emotional communication skills in leader emergence and effectiveness. Group Dynamics. Theory, Research, and Practice, 7. 83-103.

ROBBINS, S. P., JUDGE, T. A. (2012): Organizational Behavior (15th ed.) Pearson Education Prentice Hall International, Inc.

SÜMEGI E. (2017): Szociális intézmények gazdálkodása. S \& D, Budapest.

TOOMER, J., CALDWELL, C., WEITZENKORN, S., CLARK, C. (2018): Az ösztönző magatartás hatalma. 12 készség és viselkedésminta az egyéni és csapathatékonyság növelése érdekében. Pallas Athéné Könyvkiadó, Budapest.

ZACCARO, S. J. (2002): Organizational leadership and social intelligence. In RIGGIO, R. E., MURPHY, S. E., PIROZZOLO, F. J. (Eds.): LEA's organization and management series. Multiple intelligences and leadership. Lawrence Erlbaum Associates Publishers, Mahwah, NJ. 29-54. 